\title{
Pengaruh Lama Pengadukan Pada Penambahan Serbuk Kulit Buah Rambutan (Nephelium lappaceum L.) Terhadap Penurunan Bilangan Asam Dan Bilangan Peroksida Pada Minyak Jelantah
}

\author{
Sri Nuraini ${ }^{1}$, Purwadi ${ }^{2}$, Reni Anggita Putri ${ }^{3}$ \\ ${ }^{1}$ Prodi Diploma III Analis Kesehatan Poltekkes Tanjungkarang \\ ${ }^{2}$ BBPOM Provinsi Lampung \\ ${ }^{3}$ Alumni Prodi Diploma IV Analis Kesehatan Poltekkes Tanjugkarang
}

\begin{abstract}
Abstrak
Mutu minyak goreng ditentukan oleh titik asapnya. Kerusakan minyak yang utama yaitu timbulnya bau dan rasa tengik yang disebut proses ketengikan. Hal ini disebabkan oleh otooksidasi radikal asam lemak tidak jenuh dalam lemak.Otooksidasi dimulai dengan pembentukan radikal-radikal bebas yang disebabkan oleh faktor-faktor yang dapat mempercepat reaksi seperti cahaya, panas, peroksida lemak, atau hidroperoksida, dan logam-logam berat. Kerusakan minyak goreng dapat dilihat dengan memeriksa kadar bilangan asam dan bilangan peroksida pada minyak tersebut. Antioksidan merupakan senyawa yang dapat menghambat reaksi oksidasi, dengan mengikat radikal bebas.Kulit buah rambutan mengandung senyawa antioksidan seperti flavonoida. Penelitian ini bertujuan untuk mengetahui pengaruh lama pengadukan pada penambahan serbuk kulit buah rambutan terhadap penurunan kadar bilangan asam dan bilangan peroksida pada minyak goreng jelantah. Data hasil uji univariat menunjukkan bahwa setelah dilakukan penambahan serbuk kulit buah rambutan dengan variasi lama pengadukan dapat menurunkan bilangan asam dan bilangan peroksida.Data hasil uji bivariat yang dianalisis menggunakan uji Oneway Anova dengan menunjukkan nilai signifikan untuk bilangan asam dan bilangan peroksida yaitu 0,000 . Hasil tersebut menunjukan bahwa hasil uji kurang dari nilai $\alpha$ yaitu 0,05 , maka dapat disimpulkan bahwa ada pengaruh lama pengadukan pada penambahan serbuk kulit buah rambutan terhadap penurunan bilangan asam dan bilangan peroksida pada minyak jelantah.
\end{abstract}

Kata Kunci: Antioksidan, Bilangan Asam, Bilangan Peroksida, Minyak Jelantah.

\section{The Effect Of Stirring Time On The Addition Of Rambutan Fruitpowder (Nephelium lappaceum L.) To A Decrease In Acid Number And Peroxide Number In Used Cooking Oil}

\begin{abstract}
The quality of cooking oil is determined by the point of smoke. Damage to the main oil is rancid odor and taste of the so-called process of rancidity. This is caused by the otooxidation of radical fatty acids not saturated in fat. Otooksidation begins with the formation of free radicals caused by factors that can accelerate reactions such as light, heat, fat peroxide, or hydroperoxide, and heavy metals. Damage to cooking oil can be seen by checking the level of acid numbers and peroxide numbers in the oil. Antioxidants are compounds that can inhibit oxidation reactions, by binding to free radicals. Rambutan fruit skin contains antioxidant compounds such as flavonoids. This research to determine the effect of stirring time on the addition of rambutan fruit powder to a decrease in the level of acid number and peroxide number in used cooking oil. Univariate test data shows that after addition of rambutan fruit powder with a variety of stirring duration can reduce acid numbers and peroxide numbers. The bivariate test data were analyzed using the Oneway Anova test by showing significant values for acid numbers and peroxide numbers of 0,000 . These results indicate that the test results are less than the $\alpha$ value of 0.05 , it can be concluded that there is an effect of stirring time on the addition of rambutan fruit powder to the reduction of acid numbers and peroxide numbers in used cookingoil.
\end{abstract}

Keywords: Antioxidants, Acid Numbers, Peroxide Numbers, Cooking Oil.

Korespondensi : Sri Nuraini, S. Pd., M.Kes. Jurusan Analis Kesehatan. Politeknik Kesehatan Tanjungkarang. Jl. Soekarno-Hatta No: 1 Bandar Lampung. mobile 081379802531.e-mail : srinuraini291@gmail.com 


\section{Pendahuluan}

Lemak dan minyak merupakan zat makanan yang penting untuk menjaga kesehatan tubuh manusia.Selain itu lemak dan minyak juga merupakan sumber energi yang lebih efektif dibanding dengan karbohidrat dan protein. Satu gram minyak atau lemak dapat menghasilkan 9 kkal, sedangkan karbohidrat dan protein hanya menghasilkan $4 \mathrm{kkal} / \mathrm{g}$. Minyak atau lemak khususnya minyak nabati mengandung asam-asam lemak esensial seperti asam linoleat, lenolenat, dan arakidonat yang dapat mencegah penyempitan pembuluh darah akibat penumpukan kolesterol. Minyak dan lemak juga berfungsi sebagai sumber dan pelarut bagi vitamin $\mathrm{A}, \mathrm{D}, \mathrm{E}$, dan $\mathrm{K}$ (Winarno, 2004).

Lemak dan minyak terdapat pada hampir semua bahan pangan dengan kandungan yang berbeda-beda.Tetapi lemak dan minyak seringkali ditambahkan dengan sengaja ke bahan makanan dengan berbagai tujuan.Dalam pengolahan bahan pangan, minyak dan lemak berfungsi sebagai media penghantar panas, seperti minyak goreng, mentega (putih), lemak (gajih), dan margarin.Disamping itu, penambahan lemak dimaksudkan juga untuk menambah kalori serta memperbaiki tekstur dan cita rasa bahan pangan (Winarno, 2004).

Minyak merupakan bahan cair yang memiliki kandungan asam lemak tidak jenuh yang tinggi dan memiliki satu atau lebih ikatan rangkap di antara atom-atom karbonnya sehingga mempunyai titik lebur yang rendah (Winarno, 2004).

Minyak goreng berfungsi sebagai penghantar panas, penambah rasa gurih, dan penambah nilai kalori bahan pangan.Mutu minyak goreng ditentukan oleh titik asapnya, yaitu suhu pemanasan minyak sampai terbentuk akrolein yang tidak diinginkan dan dapat menimbulkan rasa gatal pada tenggorokan. Hidrasi gliserol akan membentuk aldehida tidak jenuh atau akrolein tersebut. makin tinggi titik asap, makin baik mutu minyak goreng itu. Titik asap suatu minyak goreng tergantung dari kadar gliserol bebas. Lemak yang telah digunakan untuk menggoreng titik asapnya akan turun, karena telah terjadi hidrolisis molekul lemak karena itu untuk menekan terjadinya hidrolisis, pemanasan lemak atau minyak sebaiknya dilakukan pada suhu yang tidak terlalu tinggi dari seharusnya. Pada umumnya suhu penggorengan adalah $177-221^{\circ} \mathrm{C}$ (Winarno,2004).

Kerusakan lemak yang utama yaitu timbulnya bau dan rasa tengik yang disebut proses ketengikan. Hal ini disebabkan oleh otooksidasi radikal asam lemak tidak jenuh dalamlemak.

Otooksidasi dimulai dengan pembentukan radikal- radikal bebas yang disebabkan oleh faktor-faktor yang dapat mempercepat reaksi seperti cahaya, panas, peroksida lemak, atau hidroperoksida, dan logam-logam berat seperti $\mathrm{Cu}, \mathrm{Fe}, \mathrm{Co}$, dan Mn (Winarno, 2004).

Bilangan peroksida ditentukan dengan jumlah iodin yang dibebaskan setelah lemak atau minyak ditambahkan KI.Lemak direaksikan dengan KI dalam pelarut asam asetat dan kloroform (2:1), kemudian iodin yang terbentuk ditentukan dengan titrasi memakai $\mathrm{Na}_{2} \mathrm{~S}_{2} \mathrm{O}_{3}$ (Winarno, 2004). Peroksida juga dapat mempercepat proses timbulnya bau tengik dan flavor yang tidak dikehendaki dalam bahan pangan. Jika jumlah peroksida dalam bahan pangan (lebih besar dari100) akan bersifat sangat beracun dan tidak dapat dimakan (Ketaren, 2012).

Bilangan asam merupakan ukuran dari jumlah asam lemak bebas, serta dihitung berdasarkan berat molekul dari asam lemak atau campuran asam lemak. Bilangan asam dinyatakan sebagai jumlah miligram $\mathrm{KOH} 0,1$ $\mathrm{N}$ yang digunakan untuk menetralkan asam lemak bebas yang terdapat dalam 1 gram minyak atau lemak (Ketaren, 2012). Minyak goreng yang digunakan berkali-kali (lebih dari 4 kali) akan mengalami oksidasi. Hal ini bisa menyebabkan iritasi saluran pencernaan, diare, dan kanker (Khomsan, 2003).

Pohon rambutan (Nephelium Lappaceum L.) merupakan pohon yang dapat tumbuh dan sering sekali ditanam sebagai pohon buah, kadang-kadang ditemukan tumbuh liar.Rambutan tumbuh di daerah tropis (Nuraini, 2011).

Buah rambutan mengandung karbohidrat, protein, lemak, fosfor, besi, kalsium, dan vitamin A. Kulit buah mengandung senyawa tanin, saponin, dan flavonoida.Bijinya mengandung senyawa lemak dan polifenol.Daun mengandung senyawa tanin dan saponin.Serta kulit batang mengandung senyawa tanin, saponin, flavonoida, pectic substances, dan zat besi (Permata,2007).

Menurut Ferdinan dkk (2017), nilai bilangan peroksida dengan waktu perendaman yang efektif dalam menurunkan angka peroksida yaitu pada perendaman 4 jam dengan nilai bilangan peroksida sebesar $23,11 \mathrm{meq} / \mathrm{kg}$ dengan persentase $37,27 \%$ setelah minyak 
ditambahkan dengan kulit pisang kepok (Musa normalis L.). Marlina dan Ratnawati (2015), juga melakukan penelitian tentang pengaruh penambahan ekstrak kulit manggis terhadap ketahanan oksidasi minyak goreng curah, didapatkan hasil kondisi yang terbaik adalah penambahan ekstrak kulit manggis 2,25 gram dengan waktu pengadukan 50 menit. Dari penelitian ini dapat disimpulkan bahwa kulit buah manggis berfungsi sebagai zat antioksidan.

Menurut Astuti dkk (2014), tentang pengaruh lama penambahan bawang putih (Allium sativum Linn.) dalam minyak goreng bekas pakai terhadap penurunan bilangan peroksida, di dalam penelitian tersebut diperoleh rata-rata bilangan peroksida dalam minyak goreng bekas pakai sesudah penambahan bawang putih sebanyak 50 gram dengan lama waktu $1,2,3$, dan 4 jam berturutturutadalah 4,$21 ; 2,12 ; 2,116$; dan $0,00 \mathrm{meq} / \mathrm{kg}$, sehingga disimpulkan bahwa ada pengaruh lama waktu penambahan bawang putih terhadap penurunan bilangan peroksida pada minyak goreng bekas pakai.

Suparmi dkk (2012), melakukan penelitian tentang uji aktivitas ekstrak etanol kulit buah rambutan (Nephelium lappaceum L.), disimpulkanbahwa ekstrak etanol tersebut mempunyai aktivitas sebagai antioksidan dengan mekanisme menghambat pembentukan radikal bebas asam linoleat yang sama dengan vitamin E pada setiap konsentrasinya. Serta penelitian Zulhipri dkk (2012), tentang kandungan fitokimia dan uji aktifitas antioksidan ekstrak metanol kulit buah rambutan (Nephelium lappaceum L.), disimpulkan bahwa ekstrak metanol kulit buahrambutanmengandung senyawa golongan fenolik, flavonoid,steroid, dan terpenoid, serta ekstrak metanol kulit buah rambutan memiliki aktifitas sebagai antioksidan yang sebanding dengan asam askorbat dan lebih tinggi dari pada Epigallocatechin Gallate dan Butylated Hydroxytoluene.

Dewi dkk (2012), meneliti mengenai efek ekstrak kulit buah rambutan (Nephelium lappaceum L.) terhadap peroksidasi lipid hepar tikus obesitas, disimpulkan bahwa ekstrak kulit buah rambutan mampu menurunkan peroksidasi lipid hepar tikus obesitas dengan dosis efektif yaitu $15 \mathrm{mg} / \mathrm{kg}$ BB dan 30 $\mathrm{mg} / \mathrm{kgBB}$.

Kulit rambutan yang selama ini tidak dimanfaatkan hanya dibuang dan menjadi sampah begitu saja, padahal banyak sekali manfaat yang terkandung di dalamnya.Menurut
Zulhipri dkk (2012), diketahui bahwa kulit buah rambutan memiliki banyak antioksidan, salah satunya adalah flavonoid.

\section{Metode}

Jenis penelitian yang dilakukan bersifat eksperimental dengan desain penelitian berupa quasi experimental. Terdiri dari variabel bebas yaitu pengaruh lama pengadukan pada penambahan serbuk kulitbuah rambutan (Nephelium Lappaceum L.) dan variabel terikat berupa penurunan bilangan asam dan bilangan peroksida pada minyak jelantah.

Cara kerja penelitian dimulai dengan menimbang sampel minyak sebanyak masingmasing 150 gram, kemudian dimasukan kedalam masing-masing Beaker gelas yang bersih, lalu di tambahkan serbuk kulit buah rambutan masing-masing dengan konsentrasi $23,1 \%$. Kemudian dilakukan pengadukan menggunakan shaker dan magnetik stirer dengan kecepatan $500 \mathrm{rpm}$ pada variasi lama pengadukan 15, 30, 45, 60, 75, dan 90 menit, Setelah proses selesai, kemudian minyak disaring menggunakan kertas saring biasa, Dilakukan penetapan kadar bilangan asam secara titrimetri alkalimetri dan penetapan kadar bilangan peroksida secara titrimetri iodometri. Dilanjutkan dengan perhitungan bilangan asam dan peroksida sebelum dan sesudah perlakuan. Penelitian ini dilakukan di Laboratorium Kimia Analisa Makanan dan Minuman Jurusan Analis Kesehatan Poltekkes Tanjungkarang, pada bulan Mei sampai Juni 2018.

Analisa data dalam penelitian ini menggunakan statistika uji One way Anova.

\section{Hasil}

Analisis Univariat

Tabel 1. Pemeriksaan Organoleptis terhadap MinyakGoreng

\begin{tabular}{lll}
\hline Kondisi & Bau & Warna \\
\hline Minyak baru & Normal & Kuning jernih \\
\hline Minyak jelantah & Tengik & $\begin{array}{l}\text { Kuning pekat } \\
\text { kecoklatan }\end{array}$ \\
\hline $\begin{array}{l}\text { Minyak jelantah } \\
\text { dengan } \\
\text { penambahan } \\
\text { serbuk kulit } \\
\text { rambutan }\end{array}$ & Normal & Kuning \\
\hline
\end{tabular}


Tabel 2. Rata-rata bilangan asan pada minyak baru dan minyak jelantah

\begin{tabular}{lc}
\hline \multicolumn{1}{c}{ Kondisi Minyak } & $\begin{array}{c}\text { Rata-rata bilangan asam } \\
(\mathrm{mg} \mathrm{KOH} / \mathrm{g})\end{array}$ \\
\hline Minyak goreng baru & 1,094 \\
\hline $\begin{array}{l}\text { Minyak jelantah } \\
\text { sebelum perlakuan }\end{array}$ & 7,612 \\
\hline
\end{tabular}

Tabel 3.Pemeriksaan Bilangan Asam pada Minyak jelantah yang telah Diberi Perlakuan

\begin{tabular}{|c|c|c|c|c|c|}
\hline \multirow{2}{*}{$\begin{array}{c}\text { Waktu } \\
\text { pengadukan } \\
\text { (menit) }\end{array}$} & \multicolumn{4}{|c|}{ Bilangan Asam(mgKOH/g) } & \multirow{2}{*}{$\begin{array}{l}\text { Rata- } \\
\text { rata }\end{array}$} \\
\hline & 1 & 2 & 3 & 4 & \\
\hline 0 & & & & & \\
\hline $\begin{array}{l}\text { Tanpa } \\
\text { serbuk }\end{array}$ & 7,612 & 7,612 & 7,612 & 7,612 & 7,612 \\
\hline 15 & 7,252 & 7,029 & 6,843 & 7,131 & 7,063 \\
\hline 30 & 6,933 & 5,162 & 6,372 & 5,725 & 6,048 \\
\hline 45 & 5,115 & 5,052 & 4,977 & 5,136 & 5,070 \\
\hline 60 & 5,004 & 4,926 & 4,380 & 4,520 & 4,707 \\
\hline 75 & 3,828 & 3,771 & 3,986 & 3,574 & 3,789 \\
\hline 90 & 2,491 & 2,642 & 2,460 & 2,821 & 2,603 \\
\hline
\end{tabular}

Dari tabel 3 tersebut, didapatkan penurunan hasil bilangan asam pada minyak jelantah yang telah ditambahkan serbuk kulit buah rambutan dengan variasi waktu pengadukan $15,30,45,60,75,90$ menit di mana semakin lama pengadukan serbuk kulit buah rambutan, maka didapatkan hasil bilangan asam yang semakin menurun, dari kadar bilangan asam sebesar 7,612 mg KOH/g menurun hingga kadar bilangan asam sebesar $2,603 \mathrm{mg} \mathrm{KOH} / \mathrm{g}$. Meskipun hasil tersebut masih melebihi standard bilangan asam menurut SNI 01-3741:2013 dengan kadar maksimal 0,6 mg KOH/g.

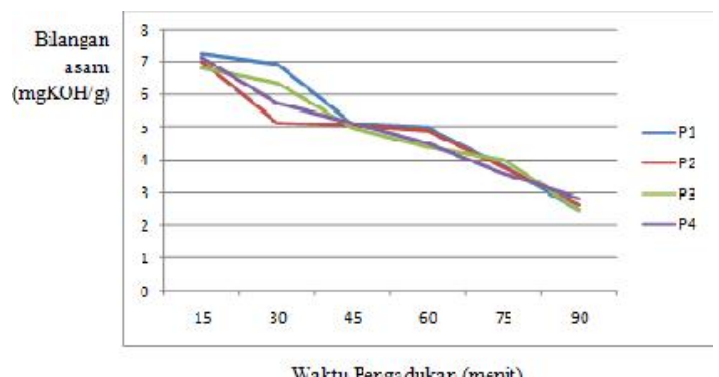

Gambar 1 Diagram Bilangan Asam Setelah Penambahan Serbuk Kulit Buah Rambutan

Berdasarkan Gambar 1 dapat dilihat bahwa dengan penambahan serbuk kulit buah rambutandengan konsentrasi $23,1 \%$ dapat menurunkan bilangan asam dengan berbedabeda sesuai dengan lama pengadukan yang digunakan. Dari diagram di atas menunjukkan garis yang semakin menurun. Jadi, semakin lama pengadukan yang digunakan maka bilangan asam semakin menurun.

Tabel 4. Rata-rata bilangan peroksida pada minyak baru dan minyak jelantah

\begin{tabular}{lc}
\hline \multicolumn{1}{c}{ Kondisi Minyak } & $\begin{array}{c}\text { Rata-rata bilangan } \\
\text { peroksida }(\mathrm{mek} \mathrm{O} / \mathrm{kg})\end{array}$ \\
\hline Minyak goreng baru & 5,235 \\
\hline $\begin{array}{l}\text { Minyak jelantah } \\
\text { sebelum perlakuan }\end{array}$ & 12,562 \\
\hline
\end{tabular}

Tabel 5. Pemeriksaan Bilangan Peroksida pada minyak jelantah yang telah diberi perlakuan

\begin{tabular}{|c|c|c|c|c|c|}
\hline \multirow{2}{*}{$\begin{array}{c}\text { Waktu } \\
\text { pengad } \\
\text { ukan } \\
\text { (menit) }\end{array}$} & \multicolumn{4}{|c|}{ Bilangan Peroksida (mek $\mathrm{O}_{2} /$ kig) } & \multirow{2}{*}{$\begin{array}{c}\text { Rata- } \\
\text { rata }\end{array}$} \\
\hline & 1 & 2 & 3 & 4 & \\
\hline $\begin{array}{c}0 \\
\text { (Tanpa } \\
\text { serbuk) }\end{array}$ & 12,562 & 12,562 & 12,562 & 12,562 & 12,562 \\
\hline 15 & 12,433 & 11,726 & 11,618 & 12,06 & 11,959 \\
\hline 30 & 12,277 & 11,485 & 10,645 & 11,387 & 11,448 \\
\hline 45 & 11,354 & 10,465 & 9,534 & 10,012 & 10,341 \\
\hline 60 & 10,811 & 9,206 & 8,923 & 9,224 & 9,541 \\
\hline 75 & 9,411 & 9,048 & 8,564 & 8,821 & 8,961 \\
\hline 90 & 8,455 & 8,121 & 8,377 & 7,399 & 8,088 \\
\hline
\end{tabular}

Dari tabel 5 tersebut, didapatkan penurunan hasil bilangan peroksida pada minyak jelantah yang telah ditambahkan serbuk kulit buah rambutan dengan variasi waktu pengadukan 15, 30, 45, 60, 75, 90 menit di mana semakin lama pengadukan serbuk kulit buah rambutan, maka didapatkan hasil bilangan peroksida yang semakin menurun. Dari kadar bilangan peroksida sebesar 12,562 mek $\mathrm{O}_{2} / \mathrm{kg}$ hingga mencapai penurunan dengankadar peroksida 8,088 mek $\mathrm{O}_{2} / \mathrm{kg}$.

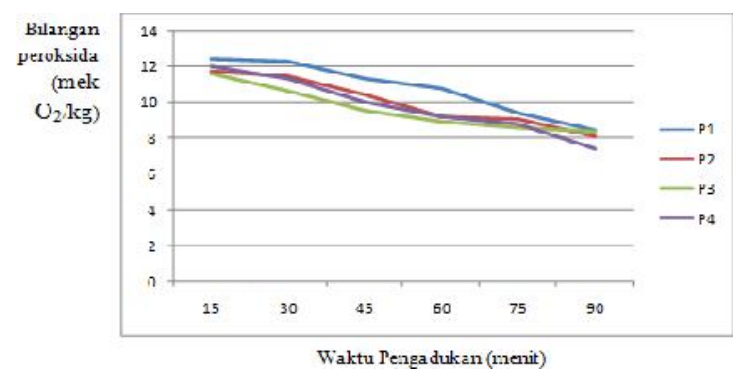

Gambar 2 Diagram Bilangan Peroksida Setelah Penambahan Serbuk Kulit Buah Rambutan

Berdasarkan Gambar 2 dapat dilihat bahwa dengan penambahan serbuk kulit buah rambutan dengan konsentrasi $23,1 \%$ dapat menurunkan bilangan peroksida dengan berbeda-beda sesuai dengan lama pengadukan yang digunakan. Dari diagram di atas menunjukkan garis yang semakin menurun. Jadi, semakin lama pengadukan yang digunakan maka bilangan peroksida semakin menurun. 
Analisis Bivariat

Tabel 6. Uji one way anova terhadap bilangan asam dan bilangan peroksida

\begin{tabular}{lccc}
\hline & $\begin{array}{c}\text { Mean } \\
\text { Square }\end{array}$ & F & Sig \\
\hline Hasil_perok & & & \\
$\begin{array}{l}\text { Between } \\
\text { Groups }\end{array}$ & 12.626 & 113.68 & .000 \\
$\begin{array}{l}\text { Within Groups } \\
\text { Hasil_asam }\end{array}$ & .111 & & \\
$\begin{array}{l}\text { Between } \\
\text { Groups }\end{array}$ & 10.907 & 33.524 & .000 \\
Within Groups & .325 & & \\
\hline
\end{tabular}

Dari hasil uji One Way Anova pada tabel 6 diperoleh nilai signifikan untuk bilangan asam yaitu0,000, dan nilai signifikan bilangan peroksida yaitu 0,000 . Hasil tersebut masih di bawah nilai kemungkinan kesalahan yang diperbolehkan yaitu sebesar 0,05 sehingga dapat dinyatakan dari hasil tersebut bahwaada pengaruh lama pengadukan pada penambahan serbuk kulit buah rambutan terhadap penurunan bilangan asam dan bilangan peroksida pada minyak jelantah.

\section{Pembahasan}

Berdasarkan penelitian yang telah dilakukan menunjukan bahwa pada sampel minyak goreng baru didapatkan hasil bilangan asam yaitu sebesar 1,094 mg KOH/g. Hasil tersebut telah melebihi nilai standard SNI 37412013 yaitu maksimal bilangan asam sebesar 0,6 $\mathrm{mg} \mathrm{KOH} / \mathrm{g}$. Setelah minyak goreng tersebut menjadi minyak jelantah, terjadi peningkatan bilangan asam hingga mencapai kadar 7,612 mg $\mathrm{KOH} / \mathrm{g}$. Hasil tersebut sudah melebihi nilai standard SNI. Pada tabel 3 menunjukkan ratarata penurunan bilangan asam yaitu dari 7,612 $\mathrm{mg} \mathrm{KOH} / \mathrm{g}$ menjadi $2,603 \mathrm{mg} \mathrm{KOH} / \mathrm{g}$ pada menit ke 90. Hasil tersebut sudah menunjukkan penurunan, tetapi masih belum memenuhi standard SNI 3741-2013.

Dari gambar 1 diagram menunjukkan bahwa setelah dilakukan penambahan serbuk kulit buah rambutan dengan variasi lama pengadukan terlihat diagram yang terus menurun. Pada diagram berwarna biru terlihat semakin menurun, di waktu 45 dan 60 menit terlihat garis yang stabil. Diagram berwarna merah terlihat semakin menurun, di waktu 30 , 45 dan 60 menit terlihat garis yang stabil. Sedangkan pada garis berwarna hijau dan ungu terlihat terus menurun. Dari diagram tersebut terlihat ada garis yang terus menurun, stabil, serta berhimpitan ini dapat disebabkan karena penimbangan massa serbuk kulit buah rambutan pada penelitian ini tidak selalu tepat 45,0 gram, dan pada proses pengadukan untuk menentukan kecepatan pengadukan masih menggunakan alat dengan pengaturan kecepatan pengadukan manual, bukan menggunakan alat dengan pengaturan kecepatan pengadukan digital. Dengan lamanya pengadukan akan mempercepat reaksi antara antioksidan pada serbuk kulit buah rambutan dengan senyawa radikal yang terdapat di dalam minyak, sehingga semakin lama pengadukan yang dilakukan maka akan semakin dapat menurunkan bilangan asam dan bilangan peroksida.

Pada tabel 6 yang menunjukkan hasil uji Oneway Anova terhadap bilangan asam diperoleh nilai signifikan untuk bilangan asam yaitu 0,000 . Hasil tersebut masih di bawah nilai alpha yaitu sebesar 0,05 sehingga dapat dinyatakan dari hasil tersebut bahwa ada pengaruh nyata lama pengadukan pada penambahan serbuk kulit buah rambutan terhadap penurunan bilangan asam.

Salah satu faktor yang dapat meningkatkan bilangan asam pada minyak dapat disebabkan karena suhu penyimpanan dan wadah yang tidak baik. Penyimpanan minyak yang baik adalah dalam tempat tertutup yang gelap dan dingin, dan wadah lebih baik terbuat dari alumunium ataupun stainless stell (Winarno, 2004). Pada minyak jelantah kemungkinan karena hidrolisis ikatan ester berupa asam karboksilat atau asam lemak oleh panas pada saat penggorengan.

Berdasarkan penelitian yang telah dilakukan menunjukan bahwa pada sampel minyak goreng baru didapatkan hasil bilangan peroksida sebesar 5,235 mek O2/kg. Hasil ini masih di bawah batas maksimum SNI 37412013 untuk bilangan peroksida yaitu sebesar 10 mek $\mathrm{O} 2 / \mathrm{kg}$. Setelah minyak goreng tersebut menjadi minyak jelantah, terjadi peningkatan bilangan peroksida hingga mencapai kadar 12,562 mek O2/kg. Setelah pemanasan hasil tersebut menunjukkan kadar di atas batas maksimum SNI 3741-2013. Pada tabel 5 didapatkan rata-rata penurunan bilangan peroksida dari 12,562 mek O2/kg hingga 8,088 mek O2/kg. Dari hasil di atas telah menunjukkan bahwa terjadi penurunan bilangan peroksida, meskipun penurunan tersebut belum mampu mencapai angka bilangan peroksida pada minyak baru sebelum digunakan.

Dari gambar 2 diagram menunjukkan 
bahwa setelah dilakukan penambahan serbuk kulit buah rambutan dengan variasi lama pengadukan garis terus menurun. Pada diagram berwarna biru, merah, hijau dan ungu, semuanya terlihat terus menurun. Pada tabel 6 yang menunjukkan hasil uji Oneway Anova terhadap bilangan peroksida diperoleh nilai signifikan untuk bilangan peroksida yaitu 0,000 . Hasil tersebut masih di bawah nilai alpha yaitu sebesar 0,05 sehingga dapat dinyatakan dari hasil tersebut bahwa ada pengaruh nyata lama pengadukan pada penambahan serbuk kulit buah rambutan terhadap penurunan bilangan peroksida.

Peningkatan bilangan asam dan bilangan peroksida dapat disebabkan oleh beberapa faktor seperti suhu, enzim, mikroba, serta penggorengan yang sering kali dilakukan terputus, artinya minyak goreng yang sudah dipakai didinginkan dan kemudian digunakan lagi untuk menggoreng, pemanasan berulang, serta dari jenis bahan pangan yang digoreng (Khomsan, 2003).

Adanya perlakukan penambahan serbuk kulit buah rambutan dengan variasi lama pengadukan mampu menghambat proses oksidasi dan mampu menghambat radikal bebas pada minyak menjadi radikal kurang aktif. Proses ketengikan sangat dipengaruhi oleh adanya prooksidan dan antioksidan. Prooksidan akan mempercepat terjadinya oksidasi, sedangkan antioksidan akan menghambatnya (Winarno, 2004).

Antioksidan merupakan senyawa yang dapat menghambat reaksi oksidasi, dengan mengikat radikal bebas dan molekul yang sangat reaktif. Akibatnya kerusakan sel akan dihambat (Winarsi, 2007). Penelitian yang dilakukan (Suparmi dkk, 2012), disimpulkan bahwa ekstrak kulit buah rambutan mempunyai aktivitas sebagai antioksidan dengan mekanisme menghambat pembentukan radikal bebas. Menurut (Tani, 2011) kulit buah rambutan mengandung antioksidan alami seperti flavonoid yang dapat menghambat proses oksidasi. Flavonoid adalah sekelompok besar antioksidan alami dalam senyawa polifenol tanaman, konsentrasi yang lebih tinggi berada pada daun dan kulit kupasannya dibandingkan dengan jaringan yang lebih dalam (Winarsi, 2007).

Senyawa polifenol dikenal sebagai antioksidan primer. Dalam proses oksidasi asam lemak, pembentukan komponen radikal terjadi pada tahap inisiasi dan propagasi, sehingga antioksidan primer menghambat oksidasi pada dua tahap tersebut.
Reaksi antioksidan primer $(\mathrm{AH})$ dalam menstabilkan komponen radikal:

$$
\begin{array}{ll}
\mathrm{R} \bullet+\mathrm{AH} & \mathrm{RH}+\mathrm{A} \bullet \\
\mathrm{RO} \bullet+\mathrm{AH} & \mathrm{ROH}+\mathrm{A} \bullet \\
\mathrm{ROO} \bullet+\mathrm{AH} & \mathrm{ROOH}+\mathrm{A} \bullet
\end{array}
$$

Dalam aksinya antioksidan primer mendonorkan atom hidrogen dari gugus hidroksil pada senyawa radikal, sehingga menjadi komponen yang non radikal dan stabil. Setelah mendonorkan atom hidrogennya antioksidan dapat menjadi senyawa radikal yang disebut radikal antioksidan. Radikal antioksidan yang terbentuk dari antioksidan primer yang telah mendonorkan atom hidrogennya mendapatkan sumbangan atom hidrogen dari antioksidan sekunder. Setelah menerima hidrogen antioksidan primer kehilangan sifat radikalnya dan kembali melakukan reaksi antioksidasi.

$$
\begin{array}{ll}
\mathrm{R} \bullet+\mathrm{A} \bullet & \mathrm{RA} \\
\mathrm{RO} \bullet+\mathrm{A} \bullet & \mathrm{ROA} \\
\mathrm{ROO} \bullet+\mathrm{A} \bullet & \mathrm{ROOA}
\end{array}
$$

(Rusdin, R 2015).

Simpulan hasil penelitian sebagai berikut: hasil pemeriksaan bilangan asam pada minyak goreng baru sebesar 1,094 mg KOH/g, setelah minyak digunakan didapatkan peningkatan bilangan asam yaitu sebesar 7,612 mgKOH/g. Hasil pemeriksaan bilangan peroksida pada minyak goreng baru sebesar 5,235 mek $\mathrm{O}_{2} / \mathrm{kg}$, setelah minyak digunakan didapatkan peningkatan bilangan peroksida yaitu sebesar $12,562 \mathrm{mekO}_{2} / \mathrm{kg}$. Serbuk kulit buah rambutan dengan konsentrasi $23,1 \%$ dan variasi waktu pengadukan dapat menurunkan bilangan asam dari rata-rata 7,612 $\mathrm{mg} \mathrm{KOH} / \mathrm{g}$ hingga menjadi $2,603 \mathrm{mg} \mathrm{KOH} / \mathrm{g}$ dan dapat menurunkan bilangan peroksida dari rata- rata 12,562 mek $\mathrm{O}_{2} / \mathrm{kg}$ hingga menjadi 8,088 mek $\mathrm{O}_{2} / \mathrm{kg}$. Terdapat pengaruh lama pengadukan pada penambahan serbuk kulit buah rambutan terhadap penurunan bilangan asam dan bilangan peroksida pada minyak jelantah.Dengan menggunakan uji Oneway Anova diperoleh nilai signifikan untuk bilangan asam yaitu 0,000 dan signifikan bilangan peroksida yaitu 0,000 . Nilai tersebut tidak melebihi nilai $\alpha$ yaitu sebesar 0,05 , sehingga dapat disimpulkan bahwa terdapat pengaruh yangkuat.

$$
\text { Berdasarkan hasil penelitian ini }
$$
dapat disarankan sebagai berikut: Masyarakat tidak menggunakan minyak goreng yang dipakai secara berulang, karena penggunaan minyak goreng secara berulang dapat merusak komponen minyak tersebut, dan dapat membahayakan kesehatankonsumen. Bagi peneliti selanjutnya, perlu dilakukan penelitian 
tentang pengaruh berbagai variasi konsentrasi serbuk kulit buah rambutan dalam penurunan bilangan asam dan bilangan peroksida pada minyak goreng, kadar air, dan cemaran logam agar dapat mengetahui kualitas minyak goreng yang lebihakurat.

\section{Daftar Pustaka}

1. Astuti, W.D, Rahayu, M, Sari, S.T 2014, Pengaruh Lama Penambahan Bawang Putih (Allium sativum Linn.) Dalam Minyak Goreng Bekas Pakai Terhadap Penurunan

2. Badan Standar Nasional Indonesia 2013, Standar Nasional Indonesia, Nomor: 3741-2013 Tentang Minyak Goreng,Jakarta.

3. Dewi, Lestari, 2012, Efek Ekstrak Kulit Buah Rambutan (Nephelium lappaceum L.)Terhadap Peroksidasi Lipid Hepar Tikus Obesitas. Jurnal Penelitian, Fakultas Matematika dan Ilmu Pengetahuan Alam Universitas Negeri Malang, Malang.

4. Ferdinan, A, Hairunnisa, Justicia AK 2017, Penurunan Bilangan Peroksida Dengan Kulit Pisang Kepok (Musa normalis L). Jurnal Ilmiah, Akademi Farmasi YARSIPontianak,Pontianak.

5. Ketaren, S 2012, Minyak dan Lemak Pangan, Universitas Indonesia,Jakarta.

6. Khomsan, A 2003, Pangan dan Gizi Untuk Kesehatan, Raja Grafindo Persada,Jakarta.

7. Kumalaningsih, S 2006, Antioksidan Alami, Tubus Agrisarana,Surabaya.

8. Marlina, L, dan Ratnawati 2015, Pengaruh Penambahan Ekstrak Kulit Manggis Terhadap Ketahanan Oksidasi Minyak Goreng Curah, Jurnal IPTEK, Vol. 1. No. 1. Institut Teknologi Indonesia,TangerangBanten.

9. Nuraini, DN 2011, Aneka Manfaat Kulit Buah dan Sayuran, C.V Andi Offset,Yogyakarta.

10. Permata, H 2007, Tanaman Obat Tradisional, Titian Ilmu,Bandung.
11. Suparmi, Anshory, H, Dirmawati, N 2012, Uji Aktivitas Antioksidan Ekstrak Etanol KulitBuah Rambutan (Nephelium lappaceum L.) Dengan Metode LinoleatTiosianat, JurnalIlmiah Farmasi, Vol. 9. No. 1. Universitas Islam Indonesia,Yogyakarta.

12. Winarno, F.G 2004, Kimia Pangan dan Gizi, PT. Gramedia Utama,Jakarta.

13. Zulhipri, Boer, Y, dan Dyaningtyas, RP 2012, Kandungan Fitokimia dan Uji Aktifitas Antioksidan Ekstrak Metanol Kulit Rambutan (Nephelim lappaceum L), JRSKT Vol. 2.No.

2.P Universitas Negeri Jakarta, Jakartz 